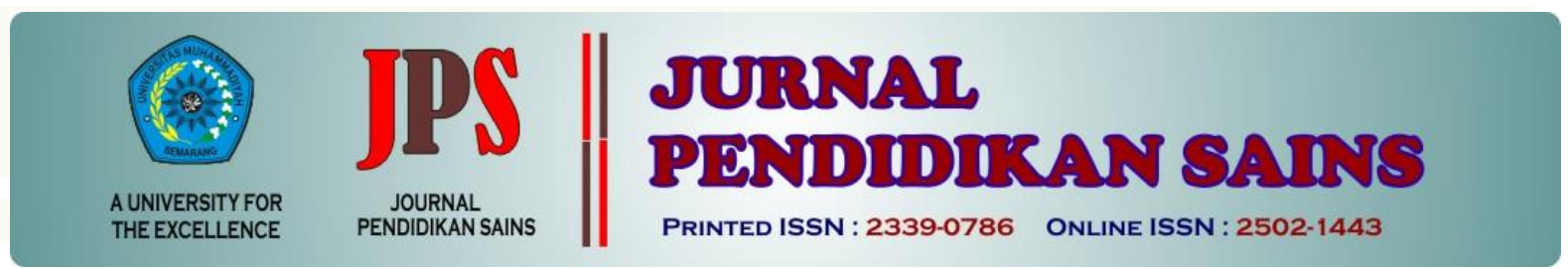

\title{
PENGEMBANGAN BUKU PANDUAN PENDIDIK BERORIENTASI CHEMO- ENTREPRENEURSHIP (CEP) PADA MATERI IKATAN KIMIA SMAIMA KELAS X
}

\author{
Oleh: ${ }^{1}$ Siti Jamilah*, ${ }^{2}$ Agus Kamaludin \\ ${ }^{1,2}$ Universitas Islam Negeri Sunan Kalijaga Yogyakarta
}

\begin{tabular}{ll}
\hline Article history & Abstract \\
\hline $\begin{array}{l}\text { Submission : 2018-12-27 } \\
\text { Revised }: 2019-02-19\end{array}$ & $\begin{array}{l}\text { This study aims to develop teacher's guidebook oriented on Chemo- } \\
\text { Accepted }: 2019-03-16\end{array}$ \\
$\begin{array}{l}\text { research is the adapted 4D model (Define, Design, Development, and } \\
\text { Disseminate). This product was validated by one material expert lecturer, } \\
\text { one media expert lecturer, three peer-reviewers, and seven chemistry } \\
\text { teachers. Its product quality was assessed by one material expert lecturer, } \\
\text { research and } \\
\text { development, teacher's } \\
\text { guidebook, chemo- } \\
\text { entrepreneurship, } \\
\text { chemical bonding }\end{array}$ & $\begin{array}{l}\text { chemistry teachers. The instrument of this research was the form of } \\
\text { product quality assessment using the Likert scale, and the form teacher } \\
\text { response instrument questionnaire using the Guttman scale. The } \\
\text { characteristics of the books developed are consisted of introductions, } \\
\text { learning competencies, learning scenarios, and learning assessments. The } \\
\text { quality of the developed book obtained the score of } 86.11 \% \text { (Very Good } \\
\text { Category) and well positive response on 92.5\%. }\end{array}$ \\
\hline
\end{tabular}

\section{Pendahuluan}

Pendidikan berhubungan erat dalam pembangunan karakter dan merupakan salah satu investasi sumber daya manusia dalam rangka mendapatkan kehidupan yang lebih baik (Wiguna, 2013: 31). Menurut Mulyasa (2013: 163) pembangunan karakter yang diimplementasikan ke dalam Kurikulum 2013 diharapkan dapat menghasilkan insan yang produktif, kreatif, dan inovatif karena kurikulum ini berbasis karakter dan kompetensi. Berdasarkan fakta di lapangan, terdapat hambatan dalam penerapan pendidikan karakter, seperti kurangnya panduan operasional dan nilai karakter dalam rencana pelaksanaan pembelajaran (RPP) hanya sebatas tulisan tanpa realisasi (Barus, 2015: 222).

Napitupulu (2013) menyatakan salah satu karakter yang ditekankan pada Kurikulum 2013 adalah karakter kewirausahaan, terutama pada tingkat SMA. TOT (Training of Trainers) Kewirausahaan Dikti (2011) menjelaskan bahwa pendidikan kewirausahaan merupakan salah satu cara untuk menumbuhkembangkan suasana akademik yang berkaitan dengan pembentukkan karakter melalui usaha penanaman nilai-nilai kejujuran, kepemimpinan, dan tanggungjawab serta semangat kerja. Pendidikan ini ditargetkan untuk menghasilkan wirausaha baru yang merupakan salah satu jawaban terhadap permasalahan pengangguran (Milla, 2013: 469). Menurut Badan Pusat Statistik (BPS) pengangguran di Indonesia masih tinggi di mana pada Februari 2018 jumlah pengangguran di Indonesia sebesar 6,87 juta orang dimana $7,19 \%$ merupakan lulusan SMA.

Alternatif yang dapat ditempuh untuk mengurangi pengangguran dengan mengaplikasikan kurikulum pendidikan bervisi kewirausahaan ke beberapa materi pelajaran yang relevan (Purwati \& Sofan Amri, 2013: 122). Salah satunya dalam pembelajaran kimia yang dikenal dengan pendekatan ChemoEntrepreneurship (CEP). Supartono (2006:

*Corresponding Author:

Nama : Siti Jamilah

Lembaga : Universitas Islam Negeri Sunan Kalijaga

Email : sitijamilah1495@gmail.com 
477) menyatakan bahwa ChemoEntrepreneurship (CEP) merupakan suatu pendekatan pembelajaran kimia yang kontekstual, yaitu pendekatan kimia yang mengaitkan materi yang sedang dipelajari dengan objek nyata. Selain memperoleh materi pelajaran, peserta didik juga mempelajari proses pengolahan suatu bahan menjadi suatu produk yang bermanfaat, bernilai ekonomi, dan menumbuhkan semangat berwirausaha. Berdasarkan hasil penelitian, pengaruh penerapan pendekatan ChemoEntrepreneurship (CEP) dalam pembelajaran kimia dapat membantu peserta didik dalam memahami materi kimia (Lestari, 2017), meningkatkan sikap positif terhadap pelajaran kimia dan minat wirausaha peserta didik (Rahmawanna, Adlim, \& Halim, 2016).

Ilmu kimia adalah ilmu yang mempelajari zat dari skala mikro, yaitu dari atom-atom dan molekul untuk menjelaskan gejala yang terjadi dalam kehidupan sehari-hari (Sukardjo \& Sari, 2007: 2). Chang (2005: 4) menyatakan bahwa dibandingkan dengan mata pelajaran yang lain, kimia sering terkesan lebih sulit, paling tidak pada tingkat dasar. Pada awalnya, mempelajari kimia seperti mempelajari bahasa yang baru dan beberapa konsepnya bersifat abstrak. Berdasarkan hasil penelitian salah satu materi kimia yang dianggap sulit menurut peserta didik adalah ikatan kimia (Smith \& Nakhleh, 2011).

Berdasarkan hasil wawancara ${ }^{1}$ dengan peserta didik SMA di Yogyakarta, salah satu materi kimia yang sulit dipahami di kelas $\mathrm{X}$ adalah materi Ikatan Kimia. Hal ini disebabkan karena materi Ikatan Kimia bersifat abstrak sehingga diperlukan daya nalar yang tinggi. Hasil penelitian juga menunjukkan bahwa peserta didik mengalami kesulitan dalam mempelajari Ikatan Kimia (Haris \& Al Idrus, 2011: 80). Menurut Haris, Muntari, \& Loka (2016: 31) peserta didik mengalami kesulitan pada materi ikatan kimia, terutama dalam menentukan senyawa yang memiliki ikatan ion, senyawa yang tidak memenuhi kaidah oktet, senyawa polar, pasangan unsur yang dapat membentuk ikatan ion dan kovalen.

Materi-materi kimia menurut pandangan pendidik termasuk dianggap sulit dalam hal konsep, mengajarkan, maupun dalam

\footnotetext{
${ }^{1}$ Wawancara dengan peserta didik kelas X MIPA 2 SMAN 1 Banguntapan pada 15 November 2017 dan peserta didik kelas XI MIPA SMA N 5 Yogyakarta pada 14 April 2018.
}

hal menilai peserta didik. Berdasarkan hal tersebut pendidik jarang menggunakan model pembelajaran dan evaluasi yang bervariatif (Haryani, Prasetya, \& Saptarini, 2014). Berdasarkan hasil wawancara ${ }^{2}$ dengan pendidik kimia SMA/MA di Yogyakarta, salah satu model pembelajaran yang jarang digunakan oleh pendidik adalah model yang berorientasi kewirausahaan sehingga peserta didik masih sulit dalam menghubungkan suatu konsep kimia dengan produk kewirausahaan. Pendidik belum menemukan buku panduan yang berorientasi kewirausahaan, bahkan masih jarang menggunakan buku panduan dalam pembelajaran karena kurang menyajikan model pembelajaran yang bervariasi.

Dalam proses belajar-mengajar, buku panduan pendidik memiliki peranan yang penting dalam rangka menunjang implementasi kurikulum, meningkatkan minat baca peserta didik, dan menjadi acuan mengajar bagi pendidik sesuai dengan pendekatan pembelajaran yang digunakan. Buku panduan pendidik merupakan buku yang memuat prinsip, prosedur, deskripsi materi pokok, dan model pengajaran untuk digunakan oleh para pendidik (Permendiknas No. 2 Tahun 2008). Permendikbud No. 65 Tahun 2014 terkait buku teks pelajaran dan buku panduan pendidik kelompok pendidikan menengah mengungkapkan bahwa hanya terdapat beberapa buku yang dapat digunakan untuk membantu pendidik dalam mendesain pembelajarannya di kelas khususnya pada pembelajaran kimia. Diharapkan dengan adanya buku panduan pendidik, pendidik dapat melakukan pembelajaran kimia yang lebih variatif dan dapat memberikan wawasan kewirausahaan kepada peserta didik.

\section{Metode Penelitian}

Jenis Penelitian

Jenis penelitian ini adalah penelitian pengembangan (Research and Developmen/R\&D). Model pengembangan dalam penelitian ini mengadaptasi model 4-D yang dikembangkan oleh Thiagarajan, terdiri dari tahap Define (pendefinisian), Design (perancangan), Develop (pengembangan), dan Disseminate (uji coba). Namun, pada penelitian ini tidak mengikutsertakan tahap Disseminate (uji coba).

\footnotetext{
${ }^{2}$ Wawancara dengan Ibu Dra. Ninik (MAN 4 Bantul) pada 6 Februari 2018 dan Ibu Bekti Mulatsih, S. Pd. (SMAN 1 Banguntapan) pada 23 Februari 2018.
} 
Waktu dan Tempat Penelitian

Penelitian dilakukan pada bulan Desember 2017 sampai dengan September 2018. Tempat yang digunakan untuk penelitian adalah SMA N 5 Yogyakarta, MAN 2 Sleman, dan MAN 4 Bantul.
Subjek Penelitian

Subjek penelitian pengembangan buku panduan pendidik yang dikembangkan dilakukan oleh dua dosen ahli, yaitu satu dosen ahli materi dan satu dosen ahli media, tiga peer review dan juga tujuh pendidik kimia SMA/MA.



Gambar 1. Gambar Prosedur Pengembangan Buku Panduan Pendidik 
Data, Instrumen, dan Teknik Pengumpulan Data

Data yang diperoleh yaitu data validasi, data penilaian kualitas, dan data respon pendidik. Data validasi berupa saran dan masukan dari dosen ahli materi, dosen ahli media, teman sejawat (peer review), dan pendidik kimia. Data penilaian kualitas berupa data kualitatif yang digunakan berupa nilai kategori, yaitu SK (Sangat Kurang), K (Kurang), C (Cukup), B (Baik), dan SB (Sangat Baik) dan data kuantitatif berupa skor penilaian, yaitu Sangat Kurang $=1$, Kurang $=$ 2, Cukup $=3$, Baik $=4$, dan Sngat Baik $=5$. Data respon pendidik berupa data kualitatif yang digunakan berupa nilai kategori, yaitu Ya (baik) dan Tidak (Tidak baik) dan data kuantitatif berupa skor penilaian, yaitu $\mathrm{Ya}=$ 1 , dan Tidak $=0$.

Instrumen yang digunakan adalah lembar validasi, lembar penilaian kualitas produk yang menggunakan teknik pengumpulan data berupa skala likert, yaitu skala lima dalam bentuk check list, dan lembar respon pendidik yang menggunakan teknik pengumpulan data berupa skala Guttman. Instrumen penilaian kualitas dan respon pendidik terdiri dari aspek kelayakan isi, kelayakan bahasa, penyajian, kegrafikaan, karakteristik buku pendidik, dan pendekatan chemo-entrepreneurship (CEP).

\section{Teknik Analisis Data}

Data validasi produk merupakan data kualitatif yang berisi saran, komentar, dan masukan. Data tersebut digunakan sebagai perbaikan buku panduan pendidik.

Data penilaian kualitas dan respon pendidik berupa kualitatif diubah menjadi data kuantitatif berdasarkan tabel berikut (Sugiyono, 2012: 135).

Tabel 1. Aturan Pemberian Skor Skala Likert

\begin{tabular}{lc}
\hline \multicolumn{1}{c}{ Keterangan } & Skor \\
\hline SK (Sangat Kurang) & 1 \\
K (Kurang) & 2 \\
C (Cukup) & 3 \\
B (Baik) & 4 \\
SB (Sangat Baik) & 5 \\
\hline
\end{tabular}

Tabel 2. Aturan Pemberian Skor Skala Guttman

\begin{tabular}{cc}
\hline Keterangan & Skor \\
\hline Ya & 1 \\
Tidak & 0 \\
\hline
\end{tabular}

Kemudian dihitung skor rata-rata setiap aspek kriteria dengan rumus berikut.

$$
\bar{X}=\frac{\sum X}{n}
$$

Keterangan:

$$
\begin{array}{ll}
\overline{\mathrm{X}} & =\text { Skor rata-rata } \\
\sum_{\mathrm{n}} \mathrm{X} & =\text { Jumlah skor } \\
& =\text { Jumlah penilai }
\end{array}
$$

Mengubah skor rata-rata penilaian kualitas yang diperoleh ke dalam kualitatif sesuai dengan kriteria penilaian ideal dengan ketentuan sebagai berikut (Sukardjo \& Sari, 2007: 83).

Tabel 3. Kriteria Kategori Penilaian Ideal

\begin{tabular}{ccc}
\hline No & Rentang skor (i) kuantitatif & $\begin{array}{c}\text { Kategori } \\
\text { Kualitatif }\end{array}$ \\
\hline 1 & $\mathrm{Xi}+1,80 \mathrm{SB} i<\mathrm{X}$ & $\mathrm{SB}$ \\
2 & $\mathrm{Xi}-0,60 \mathrm{SB} i<\mathrm{X} \leq \mathrm{Xi}+1,80 \mathrm{SB} i$ & $\mathrm{~B}$ \\
3 & $\mathrm{Xi}-0,60 \mathrm{SB} i<\mathrm{X} \leq \mathrm{Xi}+0,60 \mathrm{SB} i$ & $\mathrm{C}$ \\
4 & $\mathrm{Xi}-1,80 \mathrm{SB} i<\mathrm{X} \leq \mathrm{Xi}-0,60 \mathrm{SB} i$ & $\mathrm{~K}$ \\
5 & $\mathrm{X} \leq \mathrm{Xi}-1,80 \mathrm{SB} i$ & $\mathrm{SK}$ \\
\hline
\end{tabular}

Kemudian dari nilai rata-rata penilaian kualitas dan respon pendidik dihitung persentase keidealan tiap aspek dan keseluruhan buku panduan pendidik kimia dengan rumus berikut.

$\%$ Keidealan tiap aspek $=\frac{\text { skor rata }- \text { rata tiap aspek }}{\text { skor tertinggi ideal tiap aspek }} \times 100 \%$
$\%$ Keidealan keseluruhan $=\frac{\text { skor rata }- \text { rata seluruh aspek }}{\text { skor tertinggi ideal seluruhaspek }} \times 100 \%$

\section{Hasil Penelitian dan Pembahasan}

\section{Data proses Pengembangan}

Produk yang dikembangkan adalah buku panduan pendidik berorientasi ChemoEntrepreneursip (CEP) pada materi Ikatan Kimia. Pengembangan produk ini mengadaptasi model 4-D (define, design, develop, dan disseminate). Tahapan pengembangan yang dilakukan pada penelitian ini dibatasi hanya sampai tahap develop.

\section{Define (Pendefinisian)}

Analisis kebutuhan dilakukan dengan melakukan wawancara kepada peserta didik dan pendidik kimia di SMA N 1 Banguntapan, SMA N 5 Yogyakarta, dan MAN 4 Bantul. Wawancara ini dilakukan untuk mengetahui masalah dan hambatan yang terjadi saat proses pembelajaran di kelas. 
Berdasarkan hasil wawancara peserta didik, beberapa materi kimia sulit dipahami karena mempelajari objek pada skala mikro sehingga perlu daya nalar tinggi untuk memahaminya, salah satunya adalah materi ikatan kimia. Peserta didik mempelajari materi kimia dengan berbagai metode, namun tidak pernah dikaitkan dengan kewirausahaan.

Berdasarkan hasil wawancara dengan pendidik kimia SMA/MA, diperoleh informasi bahwa tidak ada pendidik yang menggunakan buku panduan pendidik. Hal tersebut disebabkan karena buku panduan yang tersedia kurang menyajikan model pembelajaran yang bervariasi. Dalam proses pembelajaran, pendidik juga belum pernah menyisipkan karakter wirausaha.

Analisis kurikulum dilakukan dengan cara melakukan analisis dokumen yang dijadikan sebagai pendukung pengembangan produk buku panduan pendidik. Berdasarkan analisis kurikulum diperoleh hasil bahwa kurikulum yang dipakai adalah kurikulum 2013. Materi yang digunakan adalah ikatan kimia dengan Kompetensi Inti dan Kompetensi Dasar diperoleh dari silabus kimia SMA 2017.

\section{Design (Perancangan)}

Pengumpulan referensi dilakukan dengan studi pustaka mengenai kriteria buku panduan pendidik yang baik. Referensi diambil dari buku Kimia Universitas, buku Kimia SMA, dan website resmi. Referensi yang dikumpulkan berupa materi-materi yang mendukung penyusun buku panduan pendidik yang baik. Materi-materi yang dikumpulkan diantaranya adalah materi Ikatan Kimia, keterkaitan materi dengan kehidupan seharihari, produk kewirausahaan, materi tentang model-model pembelajaran, media pembelajaran, software kimia, motivasi untuk pendidik dan materi-materi lainnya yang mendukung kompetensi, desain kegiatan, dan penilaian hasil pembelajaran.

Instrumen dibuat dari pengumpulan materi yang telah dilakukan dan mengacu ke instrumen buku pendidik kimia 2014 BSNP (Badan Standar Nasional Pendidikan). Berdasarkan hal tersebut, dihasilkan beberapa aspek antara lain aspek kelayakan isi, aspek kelayakan bahasa, aspek penyajian, aspek kegrafikaan, aspek karakteristik buku panduan pendidik, dan aspek pendekatan chemo-enterpreneurship (CEP).
Rancangan awal buku panduan pendidik dibuat menggunakan Microsoft Office Word, CorelDRAW, ACDLabs dan Avogadro. Buku panduan pendidik berupa media cetak dengan ukuran B5. Rancangan awal buku (draft I) dikonsultasikan kepada dosen pembimbing untuk diberi saran/masukan. Adapun komponen buku panduan yang dikembangkan adalah sebagai berikut:

a) Bagian awal: berisi halaman cover, identitas buku, kata pengantar, gambaran umum, petunjuk penggunaan buku, dan daftar isi.

b) Bagian inti: memuat empat bagian, yaitu pendahuluan, kompetensi pembelajaran, desain kegiatan pembelajaran, dan penilaian hasil belajar, serta terdapat kolom produk kewirausahaan.

c) Bagian akhir: berisi daftar pustaka dan lampiran LKPD (lembar kerja peserta didik) praktikum.

\section{Develop (Pengembangan)}

Tahap ini bertujuan untuk menghasilkan produk buku panduan pendidik berorientasi Chemo-Entrepreneurship yang memenuhi kriteria penilaian kualitas yang baik. Pertama adalah Revisi I. Revisi I dilakukan berdasarkan hasil masukan dan saran dari dosen pembimbing. Hasil revisi I berupa Draft II. Revisi I dilakukan setelah prototipe buku panduan pendidik dikonsultasikan kepada dosen pembimbing dengan saran dan masukan sebagai berikut:

1. Materi yang disajikan kurang lengkap.

2. Tulisan jangan menggunakan warna merah.

3. Gunakan warna terang pada nama penulis dalam cover buku.

4. Terdapat penulisan yang salah.

5. Perlu ditambah peta konsep.

Revisi II dilakukan berdasarkan hasil masukan dan saran dari dosen ahli materi, dosen ahli media, dan peer review. Hasil revisi II merupakan Draft III. Adapun masukan dan saran dari dosen ahli materi dan dosen ahli media sebagai berikut:

1. Terdapat beberapa penjelasan materi yang kurang jelas.

2. Tambahkan materi yang sekiranya dapat menambah pemahaman pendidik lebih luas.

3. Tampilkan contoh-contoh ChemoEntrepreneurship (CEP) yang lebih banyak 
4. Dibuat tambahan soal-soal remidial dan pengayaan.

5. Lembar Kerja Praktikum (LKPD) praktikum dibuat lebih lengkap.

Adapun saran dan masukan dari peer review sebagai berikut:

1. Terdapat kesalahan pada penomoran

2. Terdapat beberapa kalimat yang tumpang tindih dengan gambar

3. Resolusi gambar lebih diperbesar supaya gambar terlihat jelas

Revisi III dilakukan berdasarkan tinjauan oleh pendidik kimia. Masukan dan saran yang diberikan dijadikan bahan revisi produk yang dikembangkan. Hasil revisi III merupakan produk akhir Buku Panduan Pendidik. Adapun masukan dan saran sebagai berikut:

1. Penjabaran materi dibuat kolom terpisah dengan skenario pembelajaran supaya tidak simpang siur.

2. Terdapat beberapa penjelasan materi yang kurang jelas.

\section{Produk Hasil Pengembangan}

Hasil penelitian pengembangan ini adalah sebuah media cetak berupa buku panduan pendidik berorientasi ChemoEntrepreneurship (CEP) materi Ikatan Kimia. Buku berorientasi Chemo-Entrepreneuship (CEP) yaitu buku yang mengaitkan materi Ikatan Kimia pada objek nyata dalam kehidupan sehari-hari, khususnya pada bidang kewirausahaan sehingga kegiatan pembelajaran lebih menyenangkan dan memahami materi Ikatan Kimia lebih mudah serta dapat menambah wawasan kewirausahaan.

Buku panduan pendidik berorientasi Chemo-Entrepreneurship (CEP) materi Ikatan Kimia memuat beberapa bagian, diantaranya adalah sebagai berikut:

\section{Bagian awal}

1. Halaman cover

2. Identitas buku: berisi penyusun, dosen pembimbing, dan dosen ahli yang sebagai validator buku.

3. Kata pengantar: berisi ucapan terimakasih dan harapan penulis terhadap buku yang dikembangkan.

4. Gambaran umum isi buku: berisi gambaran umum pada setiap bagian yang ada dalam buku.
5. Petunjuk penggunaan buku: berisi tentang petunjuk penggunaan komponen yang ada pada buku.

6. Standar isi: bagian-bagian buku dan nomor urut halaman.

7. Daftar isi: berisi nomor urut halaman dari keseluruhan isi buku.

8. Peta konsep: berisi gambaran konsep yang akan dipelajari dalam materi Ikatan Kimia pada buku pendidik yang bertujuan untuk mengetahui hubungan antar konsep dan alur pembahasan.

\section{Bagian inti}

Bagian inti memuat empat bagian, yaitu pendahuluan, kompetensi pembelajaran, desain kegiatan pembelajaran, dan penilaian hasil belajar. Berikut komponen-komponen yang terdapat pada bagian inti.

1. Kolom motivasi berisi tentang kalimat motivasi untuk pendidik. Terdapat empat kolom motivasi dalam buku yang terletak di setiap awal bagian.

2. Bagian pendahuluan berisi penjelasan singkat tentang Chemo-Entrepreneurship (CEP), model-model pembelajaran, dan media pembelajaran.

3. Bagian kompetensi pembelajaran berisi kompetensi, indikator, dan alokasi waktu pembelajaran.

4. Bagian desain kegiatan pembelajaran berisi penjelasan materi beserta contoh soal dan penjelasan skenario pembelajaran beserta latihan soal dan cara mengerjakan.

5. Kolom tugas produk kewirausahaan berisi tentang penjelasan cara pembuatan suatu produk kewirausahaan. Terdapat tiga kolom tugas produk kewirausahaan, yaitu pembuatan media pembelajaran Lewis Bond, Lampu Lava, dan lilin aroma terapi.

6. Kolom software kimia berisi penjelasan singkat tentang suatu software kimia yang dapat membantu dalam penulisan kimia. Terdapat lima software kimia yang disajikan, yaitu CD/Labs, Chemdraw, Mathtype, Avogadro, dan Hyperchem.

7. Bagian penilaian hasil belajar berisi kisikisi, instrumen, dan rubrik penilaian dalam ranah afektif, kognitif, dan psikomotor.

\section{Bagian akhir}

1. Daftar pustaka: berisi daftar referensi yang digunakan dalam menyusun buku. 
2. Lampiran: berisi penjelasan suatu media pembelajaran dan LKPD praktikum yang digunakan.

3. Biodata penulis: berisi riwayat akademik penulis.

\section{Data Kualitas Produk dan Analisisnya}

Data hasil akumulasi penilaian kualitas buku panduan pendidik materi Ikatan Kimia berorientasi Chemo-Entreprenership (CEP) dapat dilihat pada tabel berikut.

Tabel 4. Tabel Penilaian Kualitas oleh Pendidik Kimia

\begin{tabular}{clcccc}
\hline No. & \multicolumn{1}{c}{ Aspek Penilaian } & $\begin{array}{c}\text { S Skor } \\
\text { Maks. Ideal }\end{array}$ & $\begin{array}{c}\text { Skor Rata- } \\
\text { rata }\end{array}$ & $\begin{array}{c}\text { Persentase } \\
\text { Keidealan }(\boldsymbol{\%})\end{array}$ & Kategori \\
\hline 1 & Kelayakan Isi & 45 & 39 & 86,67 & B \\
2 & Kelayakan Bahasa & 60 & 52 & 86,67 & SB \\
3 & Penyajian & 45 & 41 & 91,11 & SB \\
4 & Kegrafikaan & 30 & 28 & 93,33 & SB \\
5 & Karakteristik Buku Pendidik & 60 & 50 & 83,33 & B \\
6 & Pendekatan CEP & 45 & 34 & 75,56 & B \\
\hline \multicolumn{2}{r}{ Total } & $\mathbf{2 8 5}$ & $\mathbf{2 4 4}$ & $\mathbf{8 6 , 1 1}$ & SB \\
\hline
\end{tabular}

Berdasarkan penilaian dari pendidik kimia, buku panduan pendidik memiliki kualitas yang sangat baik dengan persentase sebesar $86,11 \%$. Adapun penjelasan dari setiap aspek menurut penilaian pendidik kimia adalah sebagai berikut:

Aspek kelayakan isi

Hasil penilaian kualitas pada aspek kelayakan isi menunjukkan persentase sebesar 86,67\% dengan kategori Sangat Baik. Hal tersebut menunjukkan bahwa materi yang dipaparkan sesuai dengan pendapat ahli kimia, perkembangan IPTEK, disajikan secara rinci dan jelas serta soal yang dipaparkan bervariasi dan mudah dipahami.

Aspek kelayakan bahasa

Hasil penilaian kualitas pada aspek kelayakan bahasa menunjukkan persentase sebesar 86,67\% dengan kategori Sangat Baik. Hal tersebut menunjukkan bahwa bahasa yang digunakan sesuai kaidah Bahasa Indonesia, mudah dipahami, tidak menimbulkan keraguan, serta pemakaian notasi/simbol yang sesuai.

Aspek penyajian

Hasil penilaian kualitas pada aspek penyajian menunjukkan persentase sebesar 91,11\% dengan kategori Sangat Baik. Hal tersebut menunjukkan bahwa materi yang disajikan disusun secara runtut, lengkap, dan menyertakan contoh aplikasi dalam kehidupan sehari-hari. Kekurangan pada aspek ini adalah urutan sub bab materi dan urutan penempatan materi pada skenario pembelajaran.

Aspek kegrafikaan

Hasil penilaian kualitas pada aspek kegrafikaan menunjukkan persentase sebesar 93,33\% dengan kategori baik. Hal tersebut menunjukkan bahwa grafika buku didesain dengan tepat, proporsional, dan menarik.

Aspek karakteristik buku pendidik

Hasil penilaian kualitas pada aspek karakteristik buku pendidik menunjukkan persentase sebesar 83,33\% dengan kategori sangat baik. Hal tersebut menunjukkan bahwa karakteristik buku pendidik telah terpenuhi dan setiap bagian dipaparkan dengan runtut dan mudah dipahami. Kekurangan dari aspek ini adalah soal-soal penilaian yang kurang bervariasi.

\section{Aspek pendekatan Chemo-Entrepreneurship}

Hasil penilaian kualitas pada aspek pendekatan Chemo-Entrepreneurship (CEP) menunjukkan persentase sebesar $76,56 \%$ dengan kategori Baik. Hal tersebut menunjukkan bahwa produk kewirausahaan yang dipaparkan berkaitan dengan konsep materi bab ikatan kimiadan dapat menambah wawasan kewirausahaan, serta terdapat panduan cara pembuatan produk dengan jelas. Kekurangan dari aspek ini adalah contoh produk kewirausahaan tidak terdapat pada setiap sub bab, melainkan hanya beberapa sub bab. 


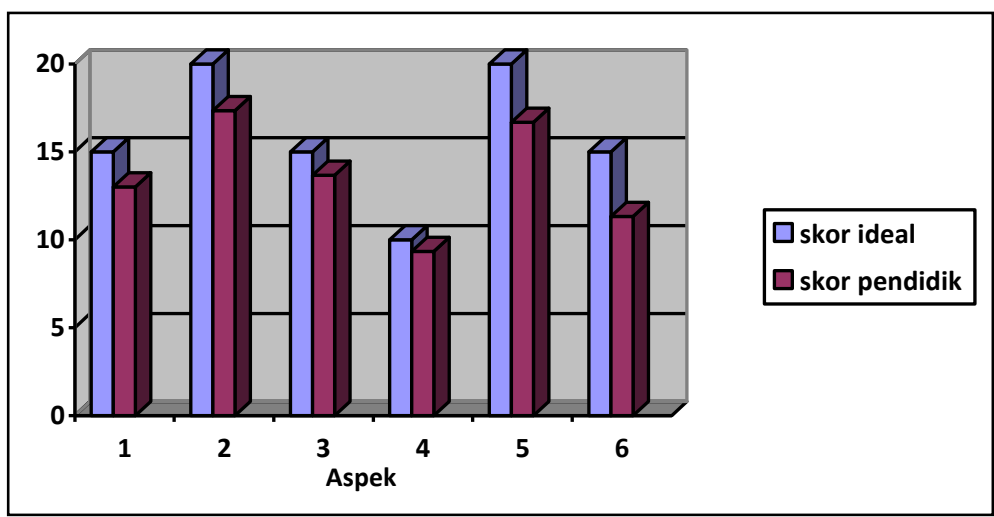

Gambar 2. Diagram Penilaian Kualitas oleh Pendidik Kimia

Buku panduan pendidik berorientasi Chemo-Entrepreneurship (CEP) materi Ikatan
Kimia direspon oleh 4 pendidik. Data respon buku pendidik dapat dilihat pada tabel berikut.

Tabel 5. Data Respon Pendidik Kimia

\begin{tabular}{|l|l|c|c|c|}
\hline No. & \multicolumn{1}{|c|}{ Aspek Penilaian } & $\begin{array}{c}\text { S Skor } \\
\text { Maks. Ideal }\end{array}$ & $\begin{array}{c}\text { Rata- } \\
\text { rata }\end{array}$ & $\begin{array}{c}\text { Persentase } \\
\text { Keidealan (\%) }\end{array}$ \\
\hline 1 & Kelayakan Isi & 4 & 1 & 100 \\
\hline 2 & Kelayakan Bahasa & 4 & 1 & 100 \\
\hline 3 & Penyajian & 8 & 2 & 100 \\
\hline 4 & Kegraikaan & 12 & 2,75 & 91,67 \\
\hline 5 & Karakteristik Buku Pendidik & 4 & 0,75 & 75 \\
\hline 6 & Pendekatan CEP & 8 & 1,75 & 87,5 \\
\hline \multicolumn{2}{|c|}{ Total } & $\mathbf{4 0}$ & $\mathbf{9 , 2 5}$ & $\mathbf{9 2 , 5}$ \\
\hline
\end{tabular}

Secara garis besar buku panduan pendidik direspon dengan sangat baik. Berdasarkan tabel 5, respon pendidik menunjukkan bahwa:

1. Materi yang disajikan sesuai dengan KI dan KD kurikulum 2013,

2. Bahasa yang disajikan mudah dimengerti,

3. Tulisan pada buku dipaparkan dengan jelas dan penyajian gambar menarik dan ukurannya proporsional,

4. Desain sampul (cover) dan isi buku menarik, namun gambar pada sampul kurang mewakili materi Ikatan Kimia,

5. Langkah pembelajaran pada buku membantu pendidik dalam menyampaikan materi secara rinci, dan materi disusun secara runtut, namun contoh penerapan penilaian dan evaluasi kurang sesuai dengan tuntutan kurikulum 2013 dikarenakan kurang menggunakan soal HOTS (High Order Thingking Skill),

6. Kegiatan proyek kewirausahaan memudahkan pendidik membangun karakter kewirausahaan peserta didik, namun kurang keterkaitan proyek kewirausahaan dengan materi.

\section{Simpulan dan Saran}

Simpulan

Produk yang dikembangkan pada penelitian ini adalah buku panduan pendidik berorientasi chemo-entrepreneurship (CEP) materi ikatan kimia untuk SMA/MA kelas X. Karakteristik buku yang dikembangkan terdiri dari pendahuluan, kompetensi pembelajaran, skenario pembelajaran, penilaian pembelajaran, dan tugas kewirusahaan pembuatan media MEc Bond, lilin aromaterapi, dan lampu lava. Buku panduan pendidik memuat informasi pendukung, yaitu kolom motivasi dan kolom software kimia. Hasil penilaian dari 3 pendidik kimia memiliki kualitas Sangat Baik (SB) dengan persentase keidealan sebesar $86,11 \%$. Hasil respon 4 pendidik kimia terhadap buku panduan pendidik mendapatkan respon sangat positif dengan persentase keidealan 92,5\%.

Saran

Buku pendidik yang telah dikembangkan perlu diuji coba secara luas untuk mengetahui kelayakan dan kekurangan setiap kompnen pembelajaran yang telah didesain dalam buku ini. Buku pendidik yang 
telah diuji coba secara luas dan telah layak digunakan dapat disebarluaskan kepada pendidik atau calon pendidik. Buku pendidik dapat dikembangkan untuk penelitian lebih lanjut dengan materi yang berbeda.

\section{Ucapan Terima Kasih}

Terimakasih disampaikan kepada kedua orang tua dan keluarga serta almamater tercinta Program Studi Pendidikan Kimia Fakultas Sains dan Teknologi UIN Sunan Kalijaga Yogyakarta.

\section{Daftar Pustaka}

Barus, G. (2015). Menakar hasil pendidikan karakter terintegrasi di SMP. Jurnal Cakrawala Pendidikan , 34(2), 222233.

BPS. (2018). Tingkat Pengangguran Terbuka (TBT) sebesar 5,13 persen, rata-rata upah buruh per bulan sebesar 2,65 juta rupiah. (2018). Retrieved from BPS: https://www.bps.go.id/pressrelease/201 8/05/07/1484/februari-2018--tingkatpengangguran-terbuka--tpt--sebesar-513-persen--rata-rata-upah-buruh-perbulan-sebesar-2-65-juta-rupiah.html.

Chang, R. (2005). Kimia dasar: Konsep-konsep inti jilid I. (M. A. Martoprawiro, Indra Noviandri, Deana Wahyuningrum, Buchari, Ismunandar, Hiskia Achmad, . . . Hidayat Muchsinuddin, Trans.) Jakarta: Erlangga.

Haris, M., \& Al Idrus, S. W. (2011). Analisis kesulitan belajar ikatan kimia ditinjau dari kesalahan konsep siswa kelas $\mathrm{X}$ SMA Negeri 3 Mataram. Jurnal Pijar MIPA, 5(2), 77-80.

Haris, M., Muntari, \& Loka, I. N. (2016). Pengembangan perangkat pembelajaran kimia dengan model pembelajaran kooperatif terpadu numbered head together dan two stay two stray dalam upaya mengatasi kesulitan belajar siswa kelas X SMA memahami konsepkonsep kimia. Jurnal Pijar MIPA, 9(1), 26-31.

Haryani, S., Prasetya, A. T., \& Saptarini. (2014). Identifikasi materi ikatan kimia SMA sulit menurut pandangan guru dan calon guru. Prossiding, Seminar

Kimia dan Pendidikan kimia.

Semarang: Universitas Negeri

Semarang.

Lestari, A. (2017). Pengembangan modul kimiaberbasis inkuiri terbimbing berorientasi chemo-entrepreneurship pada materi sifat koigafi larutan SMA/MA kelas $\mathrm{X}$ semester ganjil. skripsi UIN Sunan Kalijaga Yogyakarta.

Milla, H. (2013). Pendidikan kewirausahaan: Sebuah alternatif mengurangi pengangguran terdidik dan pencegahan korupsi. Jurnal Al-Ta'lim, 1(6), 465471.

Mulyasa. (2013). Pengembangan dan implementasi kurikulum 2013. Bandung: Rosda.

Napitupulu. (2013). Wajib pendidikan kewirausahaan di SMA. Retrieved juli 1, 2018, from kompas: https://tekno.kompas.com/read/2013/02 127/08461982/wajib.pendidikan.kewira usahaan.di.sma.

Permendikbud. (2014). Peraturan Menteri Pendidikan dan Kebudayaan Republik Indonesia No 65 tentang Buku Teks Pelajaran dan Buku Panduan Guru Kurikulum 2013 Kelompok Peminatan Pendidikan Menengah yang Memenuhi Syarat Kelayakan untuk Digunakan dalam Pembelajaran. Jakarta: Permendikbud.

Permendiknas. (2008). Peraturan Menteri Pendidikan Nasional No. 2 tentang Buku. Jakarta: Permendinas.

Purwati, L. E., \& Amri, S. (2013). Panduan memahami kurikulum 2013: Sebuah inovasi struktur kurikulum penunjang pendidikan masa depan. Jakarta: Prestasi Pustaka.

Rahmawanna, Adlim, \& Halim, A. (2016). Pengaruh penerapan pendekatan chemo-entrepreneurship (CEP) terhadap sikap siswa pada pelajaran kimia dan minat berwirausaha. Jurnal pendidikan sains Indonesia, 4(2), 113117. 
Smith, K. C., \& Nakhleh, M. B. (2011). University student's conceptions of bonding in melting and dissolving phenomena. Chemistry Education Research Practice, 12, 398-408.

Sugiyono. (2012). Metode penelitian kuantitatif, kualitatif, dan $R \& D$. Bandung: Alfabeta.

Sukardjo, \& Sari, L. P. (2007). Penelitian Hasil Belajar Kmia. Yogyakarta: UNY Press.

Supartono. (2006). Chemo-entrepreneurship (CEP) sebagai pendekatan pembelajaran kimia inovatif dan kreatif. Seminar Nasional Matematika dan Ilmu Pengethuan Alam. Semarang: Universitas Negeri Semarang.

Training of Trainer (TOT) Kewirausahaan Tahun 2011 www.dikti.go.id

Wiguna, V. I. (2013). Analisis Pengaruh PDRB pendidikan dan pengangguran terhadap kemiskinan di provinsi Jawa Tengah tahun 2005-2010. Jurnal Ilmu Ekonomi Fakultas Ekonomi dan Bisnis. 